\title{
Taxonomic notes on the tribes Tillomorphini Lacordaire, 1868 and Clytellini Miroshnikov, 2014, stat.n., with descriptions of new taxa and a third addition to review of the genus Clytellus Westwood, 1853 (Coleoptera: Cerambycidae: Cerambycinae)
}

\section{Таксономические заметки по зкукам-дровосекам триб Tillomorphini Lacordaire, 1868 и Clytellini Miroshnikov, 2014, stat.n. с описанием новых таксонов и третьим дополнением к обзору рода Clytellus Westwood, 1853 (Coleoptera: Cerambycidae: Cerambycinae)}

\author{
Alexandr I. Miroshnikov ${ }^{1,2}$ \\ А.И. Мирошников ${ }^{1,2}$
}

\footnotetext{
${ }^{1}$ Russian Entomological Society, Krasnodar, Russia. E-mail: miroshnikov-ai@yandex.ru

2 Sochi National Park, Moskovskaya str. 21, Sochi, Krasnodar region 354002, Russia.

Русское энтомологическое общество, Краснодар, Россия.

2 Сочинский национальный парк, ул. Московская 21, Сочи, Краснодарский край 354000, Россия.
}

KEY WORDS: Coleoptera, Cerambycidae, Tillomorphini, Clytellini, new status, new genus, new combination, Clytellus, new species, Borneo.

КЛЮЧЕВЫЕ СЛОВА: Coleoptera, Cerambycidae, Tillomorphini, Clytellini, новый статус, новый род, новая комбинация, Clytellus, новый вид, Борнео.

ABSTRACT. The rank of the monotypic subtribe Clytellina Miroshnikov, 2014 established within the tribe Tillomorphini Lacordaire, 1868 is elevated to the tribal level, Clytellini stat.n. The type genus of Tillomorphini, Tillomorpha Blanchard in Gay, 1851 is divided into two separate genera and a new genus, Neotillomorpha Miroshnikov, gen.n. is described. These genera are differ very distinctly from each other by the body shape, the structure of the head, antennae, palpi, pronotum, elytra, pro-, meso- and metasterna, metatarsi, and some other traits. The following new combination is established: Neotillomorpha myrmicaria (Fairmaire et Germain, 1859), comb.n. A new species, Clytellus konstantinovi Miroshnikov, sp.n. is described from Borneo. New data on Clytellus laosicus Gressitt et Rondon, 1970 and C.jenisi Miroshnikov, 2015, including those expanding their distribution area, are presented. A detailed bibliography is given.

РЕЗЮМЕ. Ранг монотипической подтрибы Clytellina Miroshnikov, 2014, установленной в составе трибы Tillomorphini Lacordaire, 1868, повышен до уровня трибы, Clytellini stat.n. Типовой род Tillomorphini - Tillomorpha Blanchard in Gay, 1851 разделён на два отдельных рода и описан новый род
Neotillomorpha Miroshnikov, gen.n. Эти роды явственно отличаются друг от друга формой тела, строением головы, усиков, щупиков, переднеспинки, надкрылий, про-, мезо- и метастернума, задних лапок и некоторыми другими признаками. Установлена следующая новая комбинация: Neotillomorpha myrmicaria (Fairmaire et Germain, 1859), comb.n. Описан новый вид Clytellus konstantinovi Miroshnikov, sp.n. с Борнео. Представлены новые данные о Clytellus laosicus Gressitt et Rondon, 1970 и C. jenisi Miroshnikov, 2015, в том числе расширяющие их ареал. Дана подробная библиография.

\section{Introduction}

The tribe Tillomorphini Lacordaire, 1868 is distributed in both the Old and New Worlds and contains more than 30 genera [Tavakilian, Chevillotte, 2020], taking into account some recent taxonomic changes [Miroshnikov, 2020]. At the same time, as noted before [Miroshnikov, 2014], the tribe requires a detailed revision.

In this paper, the suprageneric classification of the tribe, proposed by Miroshnikov [2014], is being clarified, while the type genus Tillomorpha Blanchard in

How to cite this article: Miroshnikov A.I. 2020. Taxonomic notes on the tribes Tillomorphini Lacordaire, 1868 and Clytellini Miroshnikov, 2014, stat.n., with descriptions of new taxa and a third addition to review of the genus Clytellus Westwood, 1853 (Coleoptera: Cerambycidae: Cerambycinae) // Russian Entomol. J. Vol.29. No.4. P.388-399. doi: 10.15298/rusentj.29.4.05 
Gay, 1851 is divided into two separate genera. In addition, a new species of the genus Clytellus Westwood, 1853 is described here and new data on some littleknown species of this genus are given.

The material used in this paper comes from the following institutional and private collections: ACMT American Coleoptera Museum (James Wappes) (San Antonio, Texas, USA); NHMD - Natural History Museum of Denmark, University of Copenhagen (Copenhagen, Denmark); USNM - National Museum of Natural History, Smithsonian Institution (Washington D.C., USA); cAM - coll. Alexandr Miroshnikov (Krasnodar, Russia).

\section{Tribe Tillomorphini Lacordaire, 1868}

Tillomorphides Lacordaire, 1868: 405; Lacordaire, 1869: 88; Blackburn, 1896: 38 .

Tillomorphinae, Pascoe, 1869: 640; Bates, 1870: 400; Pascoe, 1871: 274; Bates, 1885: 303; Shelford, 1902: 244.

Tillomorphini, Aurivillius, 1912: 418; Winkler, 1929: 1182; Bradley, 1930: 230, 240; Plavilstshikov, 1931: 15 (as Tillomorphina); Matsushita, 1933: 308; Linsley, 1935: 87; Wu, 1937: 719; Gressitt, 1939: 46; 1940: 84; Plavilstshikov, 1940: 533 , 753; Mitono, 1940: 128; Gressitt, 1942: 32; Knull, 1946: 225; Blackwelder, 1946: 582; McKeown, 1947: 100; Gressitt, 1951: 128, 308; 1959: 168; Arnett, 1962: 861, 888; Linsley, 1964: 179; Chemsak, 1969: 304; Gressitt, Rondon, 1970: 43, 281; Zayas, 1975: 140; Hayashi, 1975: 185; 1977: 124; Villiers, 1980: 299; Cerda, 1986: 35; Makihara et al., 1989: 298; Hüdepohl, 1990: 53; Monné, 1993: 66; MacRae, 1994: 235; Monné, Giesbert, 1995: 123; Giesbert, Chemsak, 1997: 212; Peck, Thomas, 1998: 120 Makihara, 1999: 68; Martínez, 2000: 79, 81, 90; Adlbauer, 2000 8; Monné, 2001: 7; Turnbow et al., 2003: 16; Galileo, Martins 2003: 31; Monné, 2005: 542; López-Pérez, 2005: 52; Peck, 2005 : 173; Martins, Galileo, 2005: 10; Monné, Hovore, 2005: 132; Heffern, 2005: 25; Weigel, 2006: 501; Wappes et al., 2006: 19; Monné et al., 2007: 138; Barriga, Cepeda, 2007: 9; Galileo, Martins, 2008: 53; Holzschuh, 2009: 349, 351; Bousquet et al., 2009: 56 (as Tillomorphini Pascoe, 1869); Monné et al., 2009a: 244; 2009b: 305; Löbl, Smetana, 2010: 206; Micheli, 2010: 136; Swift et al., 2010: 29; Vitali, 2010: 114; Lingafelter, 2011: 72; Peck, 2011: 35; Bouchard et al., 2011: 75, 483; Monné, Bezark, 2011: 169 (as Tillomorphini Lacordaire, 1869); Monné, 2012: 52 (as Tillomorphini Pascoe, 1869); Peck, Perez-Gelabert, 2012: 15-17, 21; Noguera et al., 2012: 621; MacRae et al., 2012: 179; Weigel et al., 2013: 98; Bezark, Monné, 2013: 174 (as Tillomorphini Pascoe, 1869); Heffern, 2013: 23; Miroshnikov, 2014: 135; Touroult, 2014: 85; Bezark, 2016: 177 (as Tillomorphini Pascoe, 1869); Ślipiński, Escalona, 2016: 17; Vitali, 2017: 148; Monné, 2020: 814 .

Epipedocerini Gahan, 1906: 305; Aurivillius, 1912: 418 (syn. pro Tillomorphini).

Type genus: Tillomorpha Blanchard in Gay, 1851

REMARKS. Relatively recently, a monotypical subtribe Clytellina was established within Tillomorphini [Miroshnikov, 2014]. However, further research showed that this subtribe deserves a higher taxonomic rank (see below).

\section{Genus Tillomorpha Blanchard in Gay, 1851}

Tillomorpha Blanchard in Gay, 1851: 482. White, 1855: 289; Fairmaire, Germain, 1859: 503; Strauch, 1861: 131; J. Thomson, 1861: 229; 1864: 195; Lacordaire, 1869: 90; Gemminger, 1872 : 2941; Bates, 1885: 59; Philippi, 1887: 774; Aurivillius, 1912: 421 Blackwelder, 1946: 583; Cerda, 1986: 35; Monné, 1993: 77; Monné, Giesbert, 1995: 125; Monné, 2005: 554; Monné, Hovore, 2005: 134; Monné et al,., 2007: 141; Monné, Bezark, 2011: 171; Monné, 2012: 53; Bezark, Monné, 2013: 177; Bezark, 2016: 179; Monné, 2020: 832 .

Type species: Tillomorpha lineoligera Blanchard in Gay, 1851, by monotypy.
COMPOSITION. The genus includes a single species (see Remarks).

DISTRIBUTION. Neotropical realm (Chile).

REMARKS. As part of the comparative morphological analysis of representatives of the tribe Tillomorphini [Miroshnikov, 2014: 142], it was noted that " $T$. myrmicaria differs from $T$. lineoligera strongly enough by a number of features and possibly deserves a new generic-level taxon of its own, being considered here within the genus Tillomorpha but provisionally".

Currently, after additional research, I have come to the conclusion that it is justified to establish a separate new genus for Tillomorpha myrmicaria Fairmaire et Germain, 1859 (see below).

Tillomorpha lineoligera Blanchard in Gay, 1851 Figs 1-3, 6, 9, 11, 13.

Tillomorpha lineoligera Blanchard in Gay, 1851: 483. Type locality: "Chili: las cercanias de Valparaiso y en Illapel" (according to the original description). Blanchard, 1854: pl. 29, figs 4a-f; White, 1855: 290; Fairmaire, Germain, 1859: 503; Strauch, 1861: 131; J. Thomson, 1861: 229; Chevrolat, 1862: 526; J. Thomson, 1864: 195; Lacordaire, 1869: 91; Gemminger, 1872: 2942; Bates, 1885: 59; Philippi, 1887: 774; Aurivillius, 1912: 421; Blackwelder, 1946: 583; Cerda, 1986: 35; Solervicens, Elgueta, 1989: 103; Barriga et al., 1993: 72; Monné, 1993: 77; Napp, 1994: 279; Monné, Giesbert, 1995: 125; Arias, 2000: 160; Monné, 2005: 554; Monné, Hovore, 2005: 134; Barriga, Cepeda, 2007: 9; Lingafelter, Nearns, 2007: 179; Monné et al., 2007: 141; Monné, Bezark, 2011: 171; Monné, 2012: 53; Bezark, Monné, 2013: 177; Miroshnikov, 2014: 142, 201, figs 1-3; Bezark, 2016: 179; Monné, 2020: 832.

Tillomorpha roitmani Cerda, 1993: 14. Type locality: Chile, Chacabuco, Til-Til, Caleu (according to the original description). Monné, Giesbert, 1995: 125; Monné, 2005: 554; Monné, Hovore, 2005: 134; Monné et al,., 2007: 141; Barriga, Cepeda, 2007: 9 (syn. pro Tillomorpha lineoligera).

MATERIAL. 107 (USNM) (Fig. 1), "Chile, EC Reed", "Tillomorpha lineoligera"; 10 (USNM), same locality, "Tillomorpha lineoligera Blanch. det. J.E. Wappes 2010"; $2 \sigma^{7}$ (USNM), "A. Faz C. Chile"; $1 \sigma^{7}, 1+$ (USNM), "Pichidangui, Chile, X.1976"; 1 ( (USNM), "Chile, Quillota, Las Palmas, 2021.XI.[19]54, F. Tippmann, Wien"; $10^{7}, 1$ ( 1 (USNM), "Quillota, Chile, F. Tippmann, Wien", "Tillomorpha lineoligera"; $10^{\top}$ (USNM), same locality; 1 \% (USNM), "Chile, Penalolen, Santiago, 30.X.[19]53, F. Tippmann, Wien"; $2 \mathrm{O}^{\text {" }}$ (USNM), "Chile, Melocoton, Santiago, 25-26.IX.[19]54, F. Tippmann, Wien"; $10^{7}$ (ACMT) (Figs 2-3), Chile, El Manzano, October 1996, "Tillomorpha lineoligera Blanch. det. J.E. Wappes"; 1 \% (USNM), "Chile"; $10^{7}, 1$ ( (NHMD), Chile, Placilla, November 1990, "Tillomorpha lineoligera Blanchard, Ole Mehl det. 2012”; 1 으 (USNM), Chile, Batuca, November 1998, "Tillomorpha lineoligera B1., Ole Mehl det. 2006".

\section{DISTRIBUTION. Chile.}

Genus Neotillomorpha Miroshnikov, gen.n. 1859.

Type species: Tillomorpha myrmicaria Fairmaire et Germain,

DIAGNOSIS. This new genus differs very distinctly from genus Tillomorpha by the body shape, the structure of the head, antennae, palpi, pronotum, elytra, pro-, meso- and metasterna, metatarsi, and some other traits. Distinguishing features of Neotillomorpha gen.n. and Tillomorpha are presented in the Table 1.

DESCRIPTION. Body small, moderately robust, almost entirely glabrous dorsally.

Head wide, at eye level barely broader than or subequal to pronotum at level of lateral tubercles; frons strongly transverse, distinctly convex; eyes with a very deep emargination 
Table 1. Distinguishing features of the genera Neotillomorpha gen.n. and Tillomorpha. Таблица 1. Отличительные признаки родов Neotillomorpha gen.n. и Tillomorpha.

\begin{abstract}
Neotillomorpha gen.n.
Body moderately compressed dorsoventrally, almost entirely shiny, as in Figs 4-5, 7, dorsally without erect setae.

Head at eye level significantly wider than pronotum at apex, as in Figs 4-5, 8, with more or less distinct, partly unclear, irregular, in places sparse or very sparse puncturation; eyes strongly convex, as in Fig. 14; temples sharply narrowed backwards, as in Figs 4-5; antennal bases moderately widely spaced, thereby shortest distance between antennal cavities significantly shorter than distance between inner margins of lower lobes of eyes, as in Fig. 14; antennomere 5 longest, clearly longer than antennomere 1, as in Figs 4, 8; maxillary palpi strongly developed, especially so in male, as in Figs 10, 14.
\end{abstract}

Pronotum at base distinctly narrower than at apex, with very well-developed, widely rounded lateral tubercles, mostly with a gentle sculpture, as in Figs 4, 8, 10, on disc strongly convex, dorsally barely constricted in front of base, as in Fig. 10.

Elytra in basal part with a coarse and very coarse sparse puncturation, as in Figs 4, 7-8; on disc at base very distinctly elevated, as in Fig. 7; each elytron with an eburneous, distinctly raised, glabrous, oblique fascia in the middle, as in Figs 4, 7-8.

Prosternal process very narrow between procoxae, as in Fig. 12; mesosternal process narrow between mesocoxae, as in Fig. 12; metasternum quite long, not less than 1.8 or 1.6 times as long as mesosternum and first (visible) abdominal sternite, respectively, as in Fig. 5

First metatarsomere strongly elongate, as in Figs 4-5, 8 .

\section{Tillomorpha}

Body strongly compressed dorsoventrally, dull dorsally, as in Figs 1-3, 6, dorsally and ventrally covered by long, erect and suberect setae.

Head at eye level subequal to pronotum at apex, as in Figs $1-3$, mostly coarsely alveolate-punctate, at least so in front and dorsally; eyes weakly convex, as in Fig. 13; temples relatively weakly narrowed backwards, as in Figs 1-3; antennal bases very widely spaced, thereby shortest distance between antennal cavities subequal to distance between inner margins of lower lobes of eyes, as in Fig. 13; antennomere 1 strongly elongate, longest, clearly longer than antennomere 5, as in Figs 1-2; maxillary palpi short, as in Figs 3, 9, 13.

Pronotum at base very clearly narrower than at apex, with barely expressed lateral tubercles, entirely with a distinctly scabrous sculpture, as in Figs 1-2, 9, on disc barely convex, dorsally quite strongly constricted in front of base, as in Fig. 9.

Elytra in basal part with a small and rough, dense, scabrous puncturation, as in Figs 1-2, 6; on disc at base almost flat, as in Fig. 6; each elytron with a narrow, oblique fascia in the middle, being formed only by dense, recumbent, white setae or, in addition, by a more or less light, partly brownish coloration of integument, but not a raised surface, as in Figs 1-2, thereby a shorter narrow fascia in basal third of the same structure as middle fascia, but it is directed obliquely downward to suture, as in Figs 1-2.

Prosternal process moderately narrow between procoxae, as in Fig. 11; mesosternal process quite wide between mesocoxae, as in Fig. 11; metasternum moderately long, not more than 1.6 or 1.2 times as long as mesosternum and first (visible) abdominal sternite, respectively, as in Fig. 3.

First metatarsomere moderately long, as in Figs 2-3.

and very well-expressed ocelli, as in Fig. 10; genae relatively short; antennae slender, moderately long, as in Figs 4-5; antennal tubercles weakly developed.

Pronotum of a peculiar shape (see Diagnosis above), strongly shiny, as in Figs 4, 8, 10; with a very small, irregular, very sparse puncturation and with individual, more or lees rough punctures, sometimes with gentle dense wrinkles; at base and near apex with a distinct scabrous sculpture.

Scutellum small, widely rounded apically.

Elytra moderately elongate, with very well-expressed humeri; distinctly narrowed towards middle starting from base, then very clearly widened in apical half, widest there, as in Figs 4, 8; each elytron with an eburneous raised fascia, being distinctly curved and directed obliquely upward to suture, nearly reaching it, as in Figs 4, 7-8.

Prosternum in profile very clearly curved, as in Fig. 10; procoxal cavities closed posteriorly, part of prosternum closing cavities posteriorly being very narrow; mesosternal process between mesocoxae clearly wider than prosternal process, but nevertheless quite narrow, as in Fig. 12; metepisterna not hidden by elytra; first (visible) abdominal sternite significantly shorter than all following (visible) sternites combined.

Legs long; femora strongly claviform; metatarsomere 1 very distinctly longer than all following metatarsomeres combined, as in Figs 4-5, 8. cies.

COMPOSITION. The new genus includes a single spe-

DISTRIBUTION. Neotropical realm (Chile).

\section{Neotillomorpha myrmicaria}

(Fairmaire et Germain, 1859), comb.n.

Figs 4-5, 7-8, 10, 12, 14.

Tillomorpha myrmicaria Fairmaire et Germain, 1859: 503. Type locality: "Chili: Concepcion [Concepción] et forêst subandines de Chillan [Chillán]" (according to the original description). Strauch, 1861: 131; Chevrolat, 1862: 526; Lacordaire, 1869: 91; Gemminger, 1872: 2942; Philippi, 1887: 774; Deflín, 1900 : 14; Aurivillius, 1912: 421; Porter, 1930: 48; Blackwelder, 1946: 583; Cerda, 1986: 35; Monné, 1993: 77; Monné, Giesbert, 1995: 125; Monné, 2005: 555; Monné, Hovore, 2005: 134; Monné et al, 2007: 141; Monné, Bezark, 2011: 171; Bezark, Monné, 2013: 177; Miroshnikov, 2014: 142, 201, figs 4-6; Bezark, 2016: 179; Monné, 2020: 832.

MATERIAL. 10 (ACMT) (Figs 4-5), Chile, Vilches Alto, January 1993, "Tillomorpha myrmicaria F. \& G. det. J.E. Wappes myrmicaria F. \& G. det. J.E. Wappes 2009"; $10^{7}$ (NHMD), same locality and date, "Tillomorpha myrmicaria, Ole Mehl det.".

DISTRIBUTION. Chile.

\section{Tribe Clytellini Miroshnikov, 2014, stat.n.}

Clytellina Miroshnikov, 2014: 137.

Type genus: Clytellus Westwood, 1853.

REMARKS. After the establishment of the subtribe Clytellina [Miroshnikov, 2014], further study of the genus Clytellus, as its only member [Miroshnikov, 2015; Miroshnikov, Tichý, 2015; Niisato, 2015], and various representatives of Tillomorphina (sensu Miroshnikov, 2014), including recent data [Touroult, 2014; Vives, 2015; Ślipiński, Escalona, 2016; Vitali, 2017; Maquart, Van Noort, 2017; Miroshnikov, Tichý, 2018; 2012"; $10^{7}$ (USNM) (Fig. 8), same locality and date, "Tillomorpha 

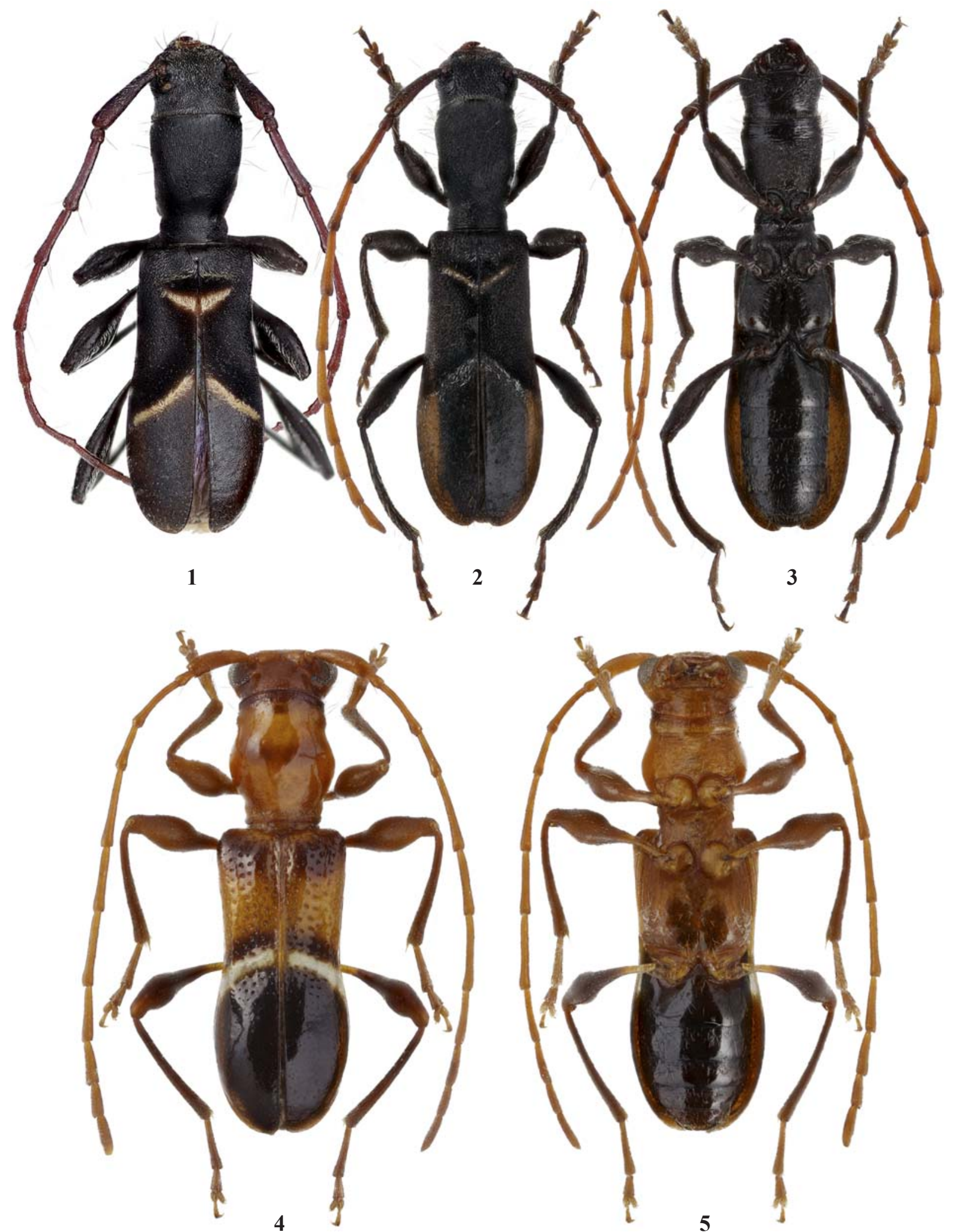

Figs 1-5. Tillomorpha and Neotillomorpha (gen.n.) spp., habitus, dorsal and ventral views: $1-3-$ T. lineoligera; 4-5 - N. myrmicaria comb.n. $(1-$ photograph by Alexander Konstantinov).

Рис. 1-5. Tillomorpha и Neotillomorpha (gen.n.) spp., общий вид, сверху и снизу: 1-3 - T. lineoligera; 4-5 $-N$. myrmicaria comb.n. $(1$ - фотография А. Константинова). 
A.I. Miroshnikov

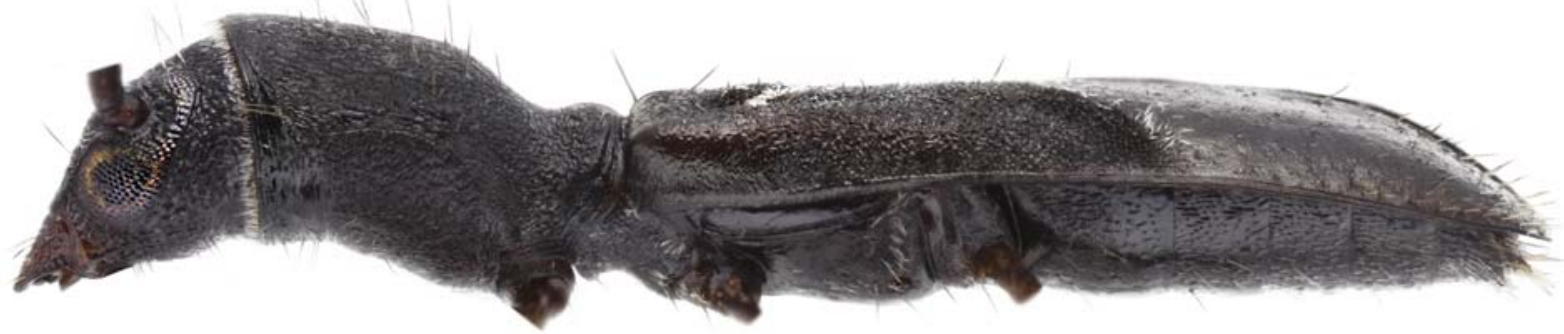

6

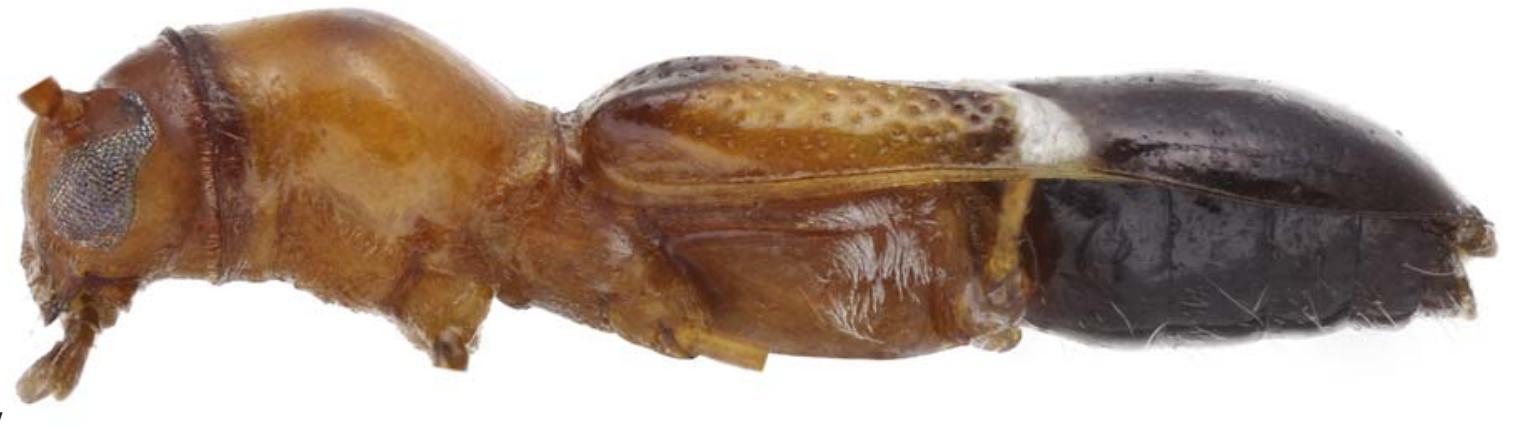

7

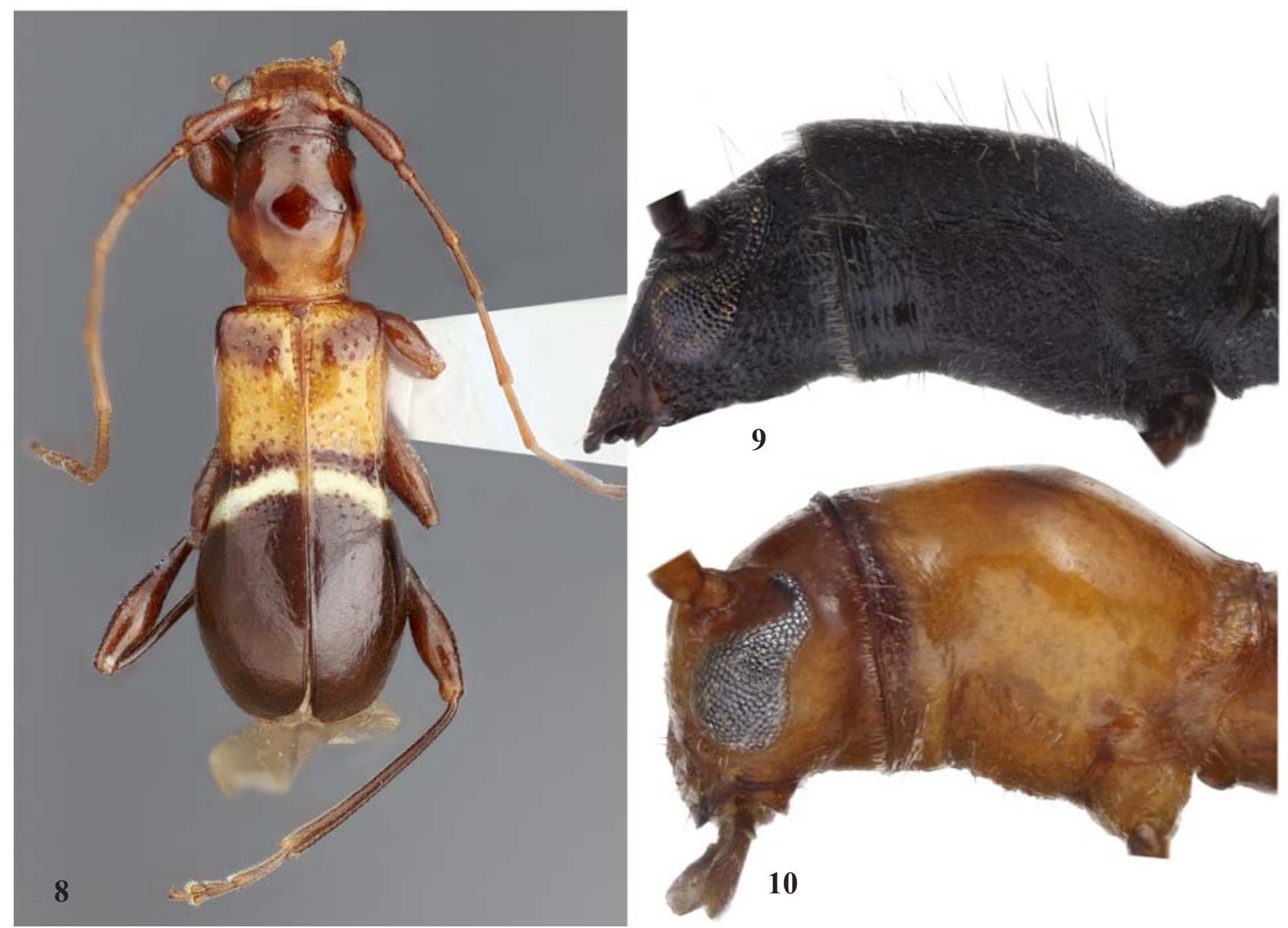

Figs 6-10. Tillomorpha and Neotillomorpha (gen.n.) spp.: 6, $9-$ T. lineoligera; 7-8, $10-$ N. myrmicaria comb.n.; 6-7 - habitus, lateral view; 8 - habitus, dorsal view; $9-10$ - head and prothorax, lateral view ( 8 - photograph by Alexander Konstantinov).

Рис. 6-10. Tillomorpha и Neotillomorpha (gen.n.) spp.: 6, 9 - T. lineoligera; 7-8, $10-$ N. myrmicaria comb.n.; 6-7 — общий вид, сбоку; 8 - общий вид, сверху; 9-10 - голова и переднегрудь, сбоку (8 - фотография А. Константинова). 
Holzschuh, 2019a, b; Botero et al., 2020; Heffern et al., 2020; Vlasák, Santos-Silva, 2020; Miroshnikov, 2020], showed the stability and reliability of all the previously noted important differences between the subtribes.
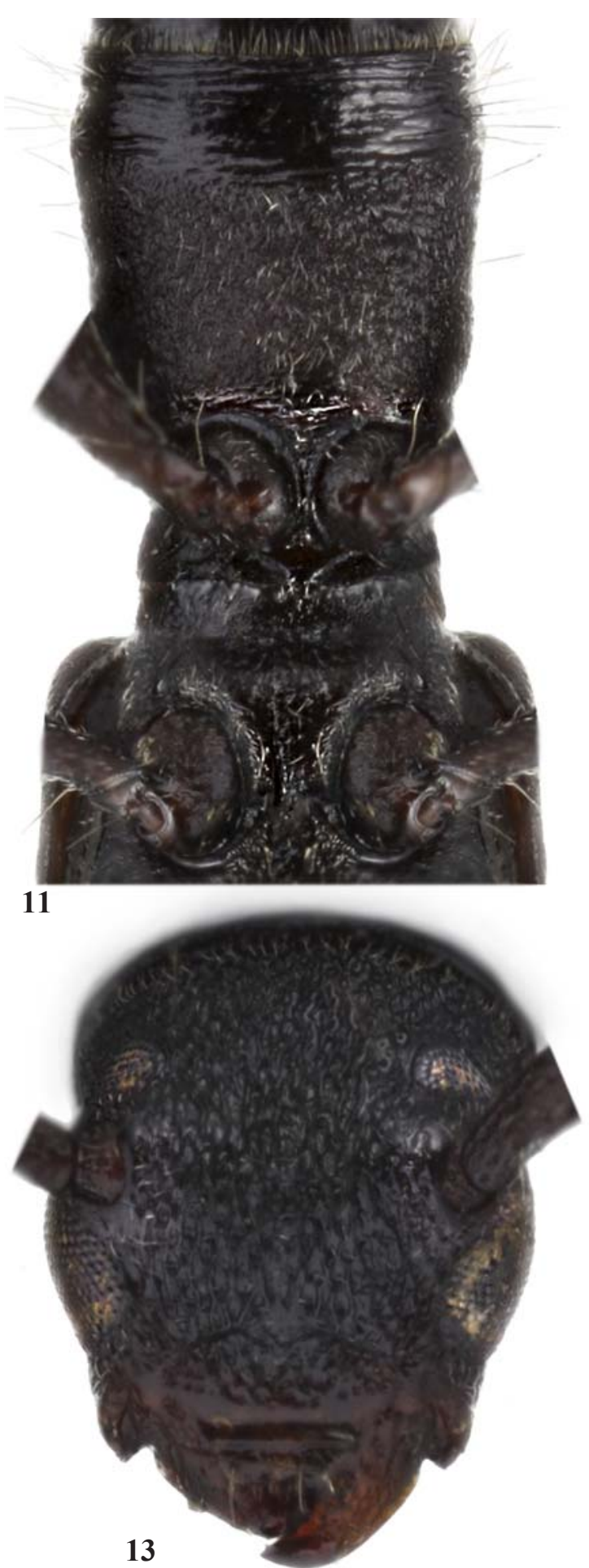

Taking into account the results of these studies and a diverse complex of taxonomically significant diagnostic features characteristic of each of the subtribes [Miroshnikov, 2014], currently, it seems quite obvious the expediency of

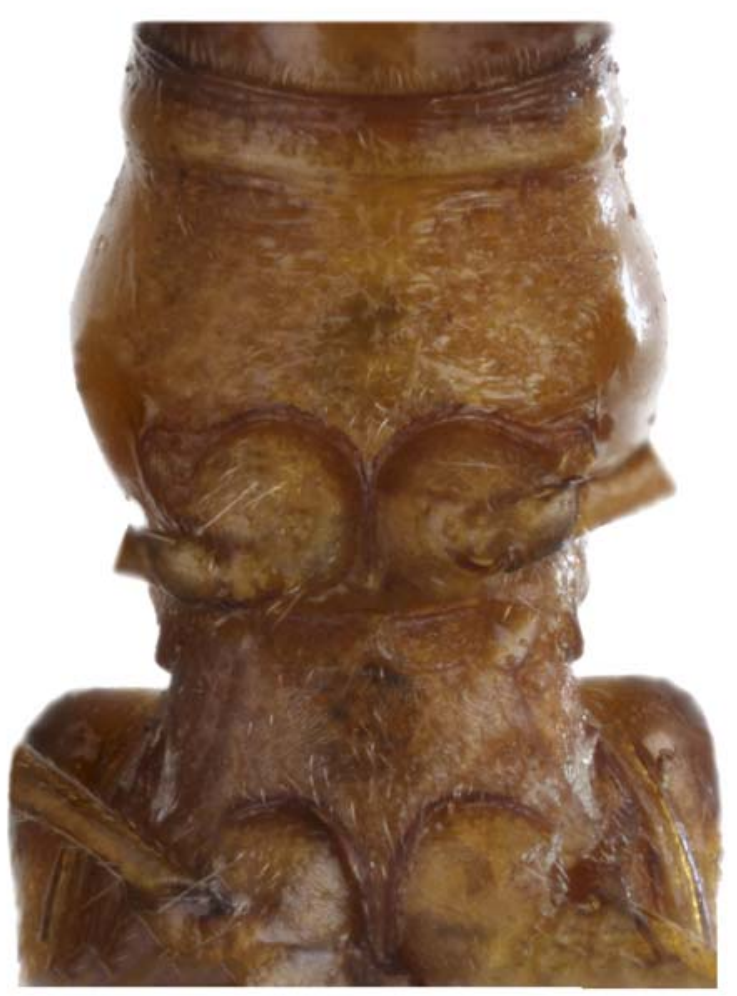

12

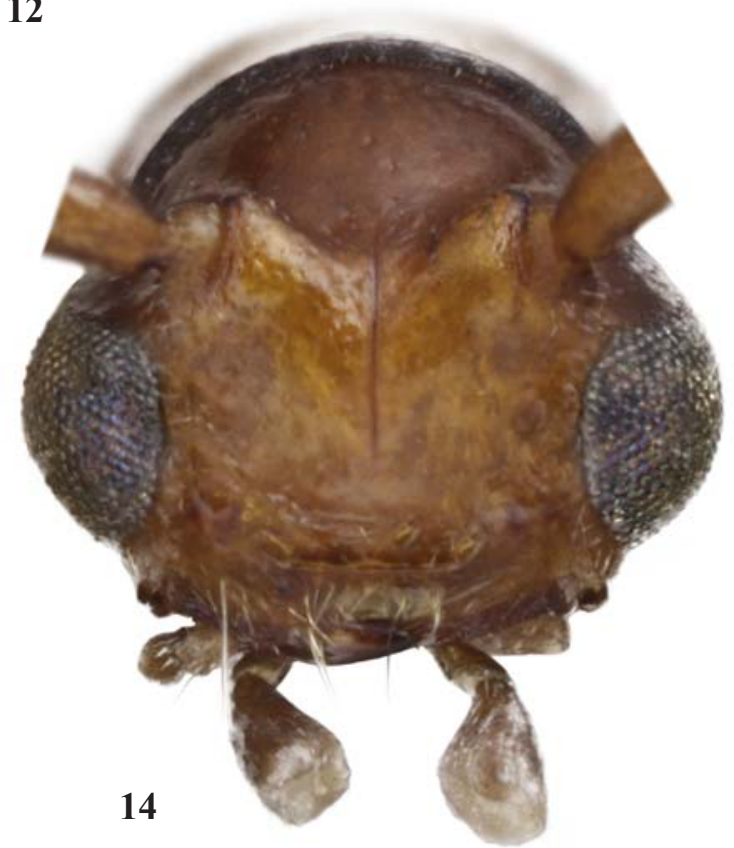

Figs 11-14. Tillomorpha and Neotillomorpha (gen.n.) spp.: 11, $13-$ T. lineoligera; 12, 14 - N. myrmicaria comb.n.; 11-12 - proand mesosterna; $13-14$ - head, frontal view.

Рис. 11-14. Tillomorpha и Neotillomorpha (gen.n.) spp.: 11, 13 - T. lineoligera; 12, $14-$ N. myrmicaria comb.n.; 11-12 - прои мезостернум; 13-14 - голова, спереди. 


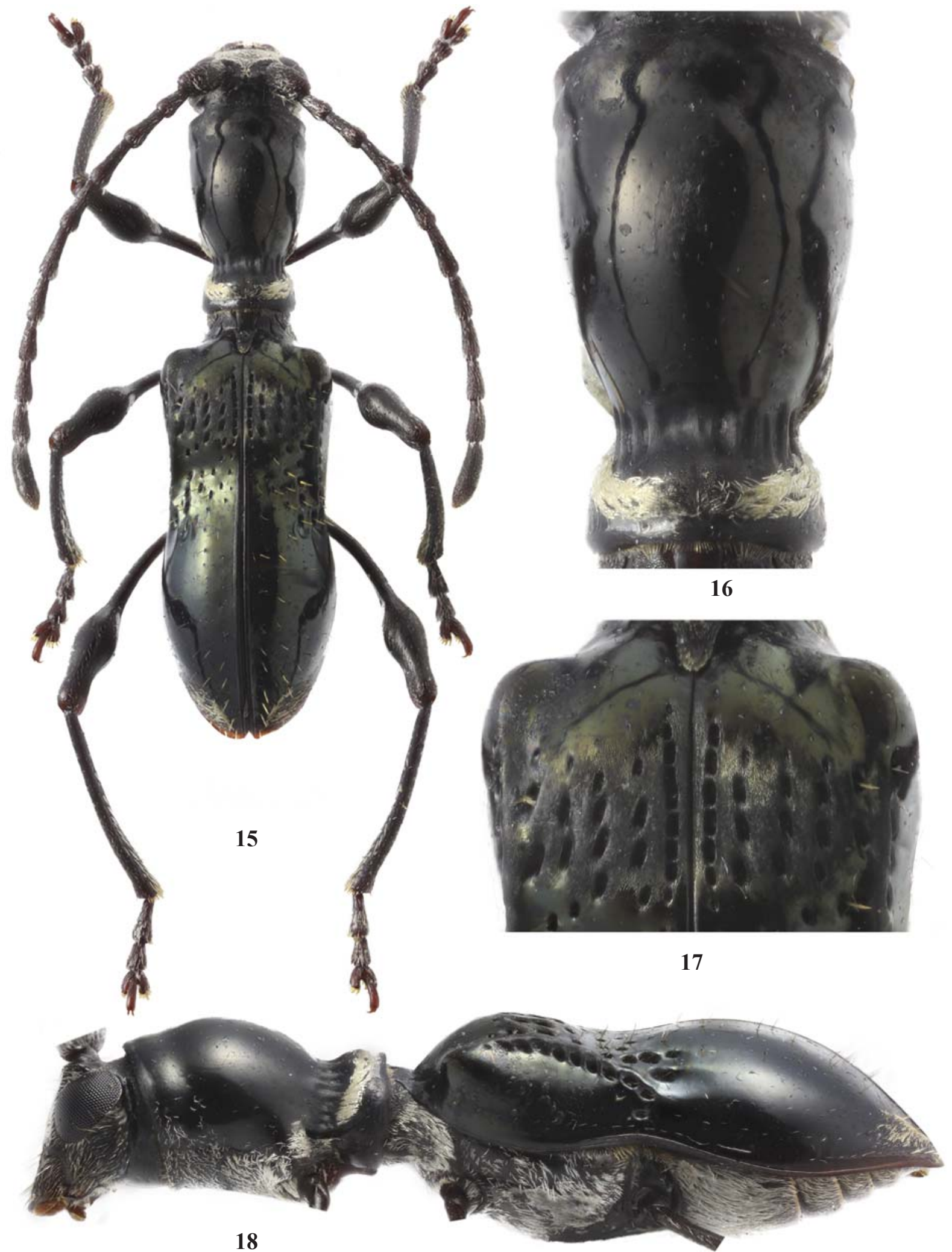

Figs 15-18. Clytellus konstantinovi sp.n., holotype, female: 15 - habitus, dorsal view; 16 - pronotum; 17 — base of elytra; 18 habitus, lateral view.

Рис. 15-18. Clytellus konstantinovi sp.n., голотип, самка: 15 - общий вид, сверху; 16 - переднеспинка; 17 - основание надкрылий; 18 - общий вид, сбоку. 
raising the rank of the subtribe Clytellina to the tribal level. Therefore, the tribe Clytellini Miroshnikov, 2014, stat.n.

Looking at the distinguishing features the tribe Tillomorphini differs it becomes clear that it more similar to some tribes, in particular Obriini Mulsant, 1839 and Anaglyptini Lacordaire, 1868, than to Clytellini stat.n.

\section{Genus Clytellus Westwood, 1853}

Clytellus Westwood, 1853: 481; 1854: 240; White, 1855: 291; Boheman, 1857: 48; J. Thomson, 1861: 379; 1864: 195; Lacordaire, 1869: 94; Pascoe, 1869: 642; Gemminger, 1872: 2943; Gahan, 1906: 312; Aurivillius, 1912: 424; Matsushita, 1933: 308; Wu, 1937: 719; Gressitt, 1939: 46; Mitono, 1940: 129; Gressitt, 1951: 310; Gressitt, Rondon, 1970: 287; Makihara et al., 1989: 299; Heffern, 2005: 25; Löbl, Smetana, 2010: 206; Heffern, 2013: 26; Miroshnikov, 2014: 137 typy

Type species: Clytellus methocoides Westwood, 1853, by mono-

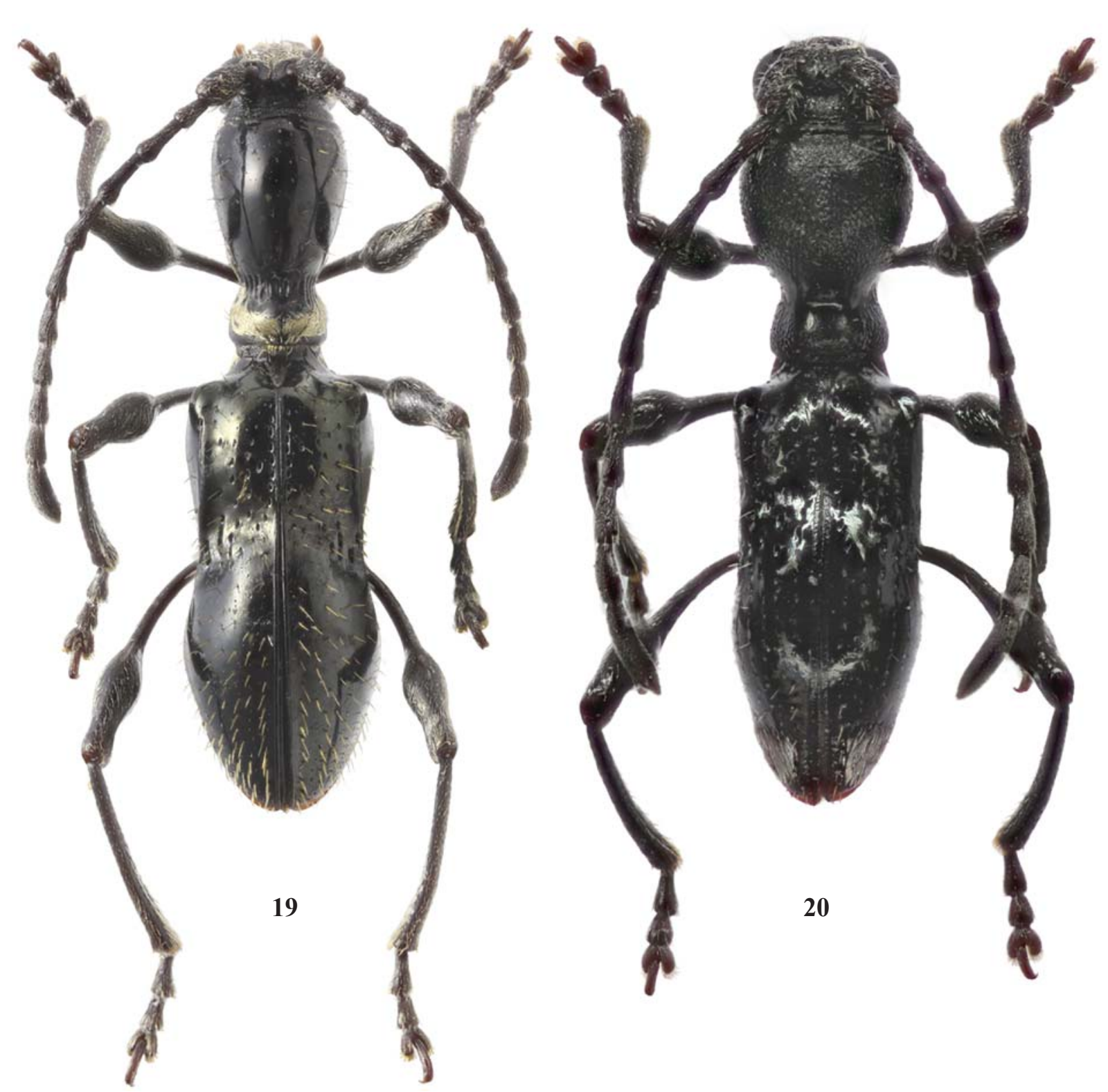

COMPOSITION. The genus includes 38 species [Miroshnikov, 2014, 2015; Miroshnikov, Tichý, 2015; Niisato, 2015], one of which is described here as new.

DISTRIBUTION. Oriental realm.

\section{Clytellus konstantinovi Miroshnikov, sp.n.} Figs $15-18$.

MATERIAL. Holotype + (NHMD) (Fig. 15), E Malaysia, Sarawak, Kuching dist., Serapi Mt., 27-29.03.1994 (leg. Sv. Bílý), "Clytellus westwoodii Pascoe", "Clytellus monilis Holzschuh, Ole Mehl det. 2012".

DIAGNOSIS. This new species seems to be especially similar to C. viridipennis Hayashi, 1977, but differs clearly at least by the presence of a distinct constriction in the apical third of the pronotum, as in Figs 15-16 (in C. viridipennis, pronotum in the apical third without any constriction), the microsculpture developed across entire width in the basal

Figs 19-20. Clytellus spp., habitus, dorsal view: $19-$ C. jenisi, female from Sarawak, Malaysia; 20 - C. laosicus, male from Vietnam. Рис. 19-20. Clytellus spp., общий вид, сверху: $19-$ - C. јеnisi, самка из Саравака (Малайзия); 20 - C. laosicus, самец из Вьетнама. 
third of the elytra, as in Fig. 17 (in C. viridipennis, microsculpture between coarse and very coarse punctures on the basal third of each elytron is located in the inner half only). Clytellus konstantinovi sp.n. can also be compared to as a yet undescribed species similar to C. viridipennis [see Miroshnikov, 2014: 160], but is distinguished through the presence of dense, recumbent, white setae at the apex of the elytra, as in Fig. 15, as well as, like from C. viridipennis, by the the presence of a distinct constriction in the apical third of the pronotum, as in Figs 15-16.

DESCRIPTION. Female. Body length $6.1 \mathrm{~mm}$, humeral width $1.5 \mathrm{~mm}$. Black; antennae, partly legs dark reddishbrown; tarsi, visible abdomen sternites, mostly, reddishbrown; elytra reddish at apex; dorsum almost entirely shiny; elytra with a distinct, metallic, greenish lustre.

Head with a flat frons; antennomere 2, 1.4 times as long as isthmus between antennal cavities; antennae slightly not reaching apical third of elytra; length ratio of antennomeres $1-11,38: 20: 28: 32: 35: 33: 29: 25: 24: 24: 42$; antennomere $2,1.65$ times as long as wide.

Pronotum 1.74 times as long as wide at apex, 2.18 times as long as width at base; apex 1.25 times as broad as base, the very base 1.32 times as broad as constriction in front of base; strongly convex; with a distinct constriction in apical third; area of constriction in front of base with coarse, longitudinal grooves very sharp both on sides and dorsally; longitudinal groove at bottom of this constriction sharply expressed; remaining surface almost smooth, only with sparse, small, mostly clear punctures.

Elytra 2.31 times as long as wide at humeral width, in apical half 1.03 times as broad as humeral width; a strong depression before middle, a moderately convex surface behind; basal part with coarse to very coarse, mostly oblongoval, heterogeneous punctures, thereby many of them located in area of a contrasting, wide, velvety, dull, microsculpture fascia covering entire width of elytra (like in some other Clytellus species, e.g. C. olesteroides Pascoe, 1885 or C. gressitti Miroshnikov, 2014); on sides with a longitudinal, long, sharply expressed groove formed by coarse, oblongoval, very dense punctures; apical part with small punctures forming on each elytron more or less clear, longitudinal, long rows.

Prosternum with an obliterated sculpture; its profile barely curved in apical part (Fig. 18); prosternal process at apex about as wide as between procoxae; mesosternal process between mesocoxae barely narrower than prosternal process between procoxae; metepisterna with a very distinct denticle at apex; first (visible) abdominal sternite 1.43 times as long as all following (visible) sternites combined.

Last tarsomere with two claws not fused at base.

Setation mainly as follows: base of pronotum in the form of a well-developed fascia (Figs 15-16), apex of elytra (Fig. $15)$, partly prosternum, most of mesosternum, almost complete metasternum and first (visible) abdominal sternite, as well as partly legs clothed with more or less dense, recumbent, white setae, partly with a silver tint; head, antennae, partly pronotum, as well as venter and legs covered by similar, but sparser setae; head, partly antennae, pronotum on sides at apex, elytra, venter and, partly, legs with more or less long, sparse, on elytra mainly more robust, erect or suberect, light setae, thereby on elytra being mostly yellowish.

ETYMOLOGY. I am pleased to dedicate this new species to my friend and colleague, Dr. Alexander S. Konstantinov (National Museum of Natural History, Smithsonian Institution, Washington D.C., USA), who constantly provides his great help to my research.
Clytellus jenisi Miroshnikov, 2015

Fig. 19.

MATERIAL. 19 (NHMD) (Fig. 19), E Malaysia, Sarawak, Kapit dist., Rumah Ugap vill., Sut. riv., 3-9.03.1994 (leg. Sv. Bílý). DISTRIBUTION. This species was described from Sabah, Malaysia [Miroshnikov, 2015].

Based on the studied material, $C$. jenisi is being recorded here from Sarawak, Malaysia for the first time.

BIONOMICS. The holotype was collected at the end of May [Miroshnikov, 2015], while the studied specimen was observed during the first decade of March.

REMARKS. The body length of the studied female is 5.6 $\mathrm{mm}$, the humeral width is $1.35 \mathrm{~mm}$.

\section{Clytellus laosicus Gressitt et Rondon, 1970}

Fig. 20.

MATERIAL. $10^{7}$ (cAM) (Fig. 20), Vietnam, Quang Nam Prov., Tay Giang Distr., 1300 m, 05.2019 (local collector).

DISTRIBUTION. This species has hitherto been known only from northern Laos [Gressitt, Rondon, 1970; Miroshnikov, 2014, 2015].

Based on the studied material, C. laosicus is being recorded here from central Vietnam for the first time.

BIONOMICS. In northern Laos, adults active from about mid-February at least to the second half of March [Gressitt, Rondon, 1970; Miroshnikov, 2014]. In central Vietnam, one specimen was collected in May.

REMARKS. The body length of the studied male is 4.2 $\mathrm{mm}$, the humeral width is $1.0 \mathrm{~mm}$.

Acknowledgements. I am very grateful to Alexander S. Konstantinov (USNM), Alexey Yu. Solodovnikov (NHMD), James E. Wappes (ACMT) for the opportunity to study the museum material, again to Alexander S. Konstantinov for the helpful provision of a series of high-quality photographs of some Tillomorphini species and a valuable information used in the present paper. I give special thanks to Kirill V. Makarov (Moscow Pedagogical State University, Moscow, Russia) for having rendered his great help in the preparation of most pictures and to my wife Tatiana P. Miroshnikova who helped a lot in the preparation of the illustrations for publication.

\section{References}

Adlbauer K. 2000. Neue Bockkäfer aus dem Transvaal Museum mit weiteren taxonomischen Bemerkungen (Coleoptera: Cerambycidae, Cerambycinae) // Coleoptera. Bd.4. S.1-12.

Arias E. 2000. Coleopteros de Chile (Chilean Beetles). Santiago: Fototeknika. $210 \mathrm{pp}$.

Arnett R.H. 1962. The beetles of the United States (A manual for identification). Washington: The Catholic University of America Press. xi $+1112 \mathrm{pp}$.

Aurivillius Chr. 1912. Cerambycidae: Cerambycinae // Coleopterorum Catalogus, auspiciis et auxilio W. Junk, editus a S. Schenkling. Pars 39. Berlin: W.Junk. P.3-574.

Bates H.W. 1870. XIX. Contributions to an insect fauna of the Amazon Valley (Coleoptera, Cerambycidae) // Transactions of the Entomological Society of London. Vol.18. P.391-444.

Bates H.W. 1885 [1879-1886]. Longicornia. Supplement. P.249$436+$ pls $17-25 / /$ F.D. Godman, O. Salvin (Eds). Biologia Centrali-Americana. Insecta. Coleoptera. Vol. 5. London: Taylor and Francis. xii +525 pp. +26 pls.

Barriga J.E., Curkovic T.M., Fichet T., Henríquez J.L,. Macaya J. 1993. Nuevos antecedentes de coleópteros xilofagos y plantas hospederas en Chile, con una recopilación de citas previas // Revista Chilena de Entomología. Vol.20. P.65-91. 
Barriga J.E., Cepeda D.E. 2007. Nuevas sinonimias en Cerambycidae de Chile (Coleoptera) // Revista Chilena de Entomología. Vol.33. P.5-13.

Bezark L.G. 2016. Checklist of the Oxypeltidae, Vesperidae, Disteniidae and Cerambycidae, (Coleoptera) of the Western Hemisphere. 497 pp. Available from: https:/www.zin.ru/Animalia/ Coleoptera/Rus/whemis16.htm

Bezark L.G., Monné M.A. 2013. Checklist of the Cerambycidae and related families (Coleoptera) of the Western Hemisphere 2013 Version. 484 pp. Available from: https://www.zin.ru/Animalia/ Coleoptera/rus/allpdf16.htm

Blackburn T. 1896. Further notes on Australian Coleoptera, with descriptions of new genera and species // Transactions and Proceedings and Report of the Royal Society of South Australia. Vol.10. P.35-109.

Blackwelder R.E. 1946. Checklist of the coleopterous insects of Mexico, Central America, the West Indies and South America. Part 4 // Bulletin of the United States National Museum. No.185. P.551-763.

Blanchard E. 1851. Tercera raza. Cerambicianos // C. Gay. Historia fisica y politica de Chile segun documentos adquiridos en esta republica durante doce años de residencia en ella y publicada bajo los auspicios del supremo gobierno. Zoologia. T.5. Paris: Museo de historia natural de Santiago. P.445-521.

Blanchard E. 1854. Coleopteros [Cerambicianos] Lam. [Pls] 27-30 // C. Gay. Atlas de la historia fisica y politica de Chile. T.2. Paris: Imprenta de E. Thunot y $\mathrm{C}^{\mathrm{a}} .135$ pls.

Boheman C.H. 1857. Berättelse om Framstegen i Insekternas, Myriapodernas och Arachnidernas Naturalhistoria för 1853 och 1854. Stockholm: P.A. Norstedt \& Söner. 295 S

Botero J.P.R., Bezark L., Santos-Silva A. 2020. A new genus, new species and taxonomic notes on American Cerambycinae (Coleoptera, Cerambycidae) // Zootaxa. Vol.4758. P.157-175.

Bouchard P., Bousquet Y., Davies A.E., Alonso-Zarazaga M.A., Lawrence J.F., Lyal C.H.C., Newton A.F., Reid C.A.M., Schmitt M., Ślipiński S.A., Smith A.B.T. 2011. Family-group names in Coleoptera (Insecta) // ZooKeys. Vol.88. P.1-972. doi: 10.3897/ zookeys.88.807

Bousquet Y., Heffern D.J., Bouchard P., Nearns E. 2009. Catalogue of family-group names in Cerambycidae (Coleoptera) // Zootaxa. Vol.2321. P.1-80.

Bradley J.C. 1930. A manual of the genera of beetles of America north of Mexico. Keys for the determination of the families, tribes and genera of Coleoptera with a systematic list of the genera and higher groups. Ithaca: Daw, Illston \& Co. 360 pp.

Cerda M. 1986. Lista Sistemática de los Cerambícidos chilenos (Coleoptera: Cerambycidae) // Revista Chilena de Entomología. Vol.14. P.29-39.

Cerda M. 1993. Nuevos Cerambicidos de Chile (Coleoptera: Cerambycidae) // Revista Chilena de Entomología. Vol.20. P.13-14.

Chemsak J.A. 1969. Records and descriptions of Mexican and Central American Tillomorphini (Coleoptera: Cerambycidae) // The Pan-Pacific Entomologist. Vol.45. No.4. P.303-317.

Chevrolat L.A.A. 1862. Description de Clytides Américains // Annales de la Société Entomologique de France. Ser.4. T.2. P.517-536.

Deflín F.T. 1900. Datos para el conocimiento de los Coleópteros e Himenópteros del Departamento de Talcahuano // Revista Chilena de Historia Natural. Vol.4. No.1. P.8-14.

Fairmaire L., Germain P. 1859. Révision des Coléoptères du Chili // Annales de la Société Entomologique de France. T.7. P.483-532.

Gahan C.J. 1906. Cerambycidae // The fauna of British India, including Ceylon and Burma. Coleoptera. Vol. 1. London: Taylor and Francis. xviii +329 pp.

Galileo M.H.M., Martins U.R. 2003. Cerambycidae (Coleoptera) da Colômbia. III. Cerambycinae com olhos finamente granulados // Iheringia, Série Zoologia. Vol.93. No.1. P.31-36.

Galileo M.H.M., Martins U.R. 2008. Novos Cerambycinae (Cerambycidae) da Região Neotropical // Papéis Avulsos de Zoologia. Vol.46. No.7. P.49-54.

Gemminger M. 1872. Cerambycidae // M. Gemminger, E. Harold (Eds.). Catalogus Coleopterorum hucusque descriptorum synonymicus et systematicus. T.9. Scolytidae, Brenthidae, Anthotribidae, Cerambycidae. Monachii: E.H. Gummi(G. Beck). P.2751-
$2988+11 \mathrm{pp}$.

Giesbert E.F., Chemsak J.A. 1997. A review of the genus Euderces Leconte (Coleoptera: Cerambycidae: Tillomorphini) // Proceedings of the California Academy of Sciences. Vol.49. No.8. P.211-286.

Gressitt J.L. 1939. A study of the longicorn beetles of Kwangtung Province, S. China (Coleoptera: Cerambycidae) // Lingnan Science Journal. Vol.18. No.1. P.1-122+ pls1-3.

Gressitt J.L. 1940. The longicorn beetles of Hainan Island (Col., Cer.) // The Philippine Journal of Science. Vol.72. Nos1-2. P.1-239.

Gressitt J.L. 1942. A provisional synopsis of the longicorn beetles of China - subfamily Cerambycinae // Lingnan Natural History Survey \& Museum. Special Publication. No.4. P.1-34.

Gressitt J.L. 1951. Longicorn beetles of China // P. Lepesme (Ed.). Longicornia. Etudes et notes sur les Longicornes. Vol.2. Paris: Paul Lechevalier. 667 pp. +22 pls.

Gressitt J.L. 1959. Longicorn beetles from New Guinea, 1 (Cerambycidae) // Pacific Insects. Vol.1. No.1. P.59-171.

Gressitt J.L., Rondon J.A. 1970. Cerambycids of Laos (Disteniidae, Prioninae, Philinae, Aseminae, Lepturinae, Cerambycinae) // J.L. Gressitt, J.A. Rondon, S. von Breuning (Eds.). Cerambycidbeetles of Laos. Pacific Insects Monograph. Vol.24. Honolulu: Entomology Department, Bernice P. Bishop Museum. P.1-314.

Hayashi M. 1975. On some longicorn beetles from Borneo and Malaya, chiefly from the entomological result of Dr. M. Hayashi's S.E. Asian Expedition in 1970 (Col.: Cerambycidae) // Bulletin of the Osaka Jonan Women's Junior College. Vol.10 (May). P.167-209+ 6 pls.

Hayashi M. 1977. Study on Cerambycidae from West Malaysia (Col.). Part 1 // Bulletin of the Osaka Jonan Women's Junior College. Vol.12 (November). P.93-128.

Heffern D.J. 2005. Catalog and Bibliography of Longhorned Beetles from Borneo (Coleoptera: Cerambycidae). Electronic Version, 2005.1. 102 pp.

Heffern D.J. 2013. A Catalog and Bibliography of Longhorned Beetles from Borneo (Coleoptera: Cerambycidae, Disteniidae and Vesperidae). Electronic Version, 2013.1. 107 pp. Available at: https://www.zin.ru/animalia/coleoptera/pdf/ heffern 2013 borneo catalog.pdf(accessed 17 October 2020).

Heffern D.J., Botero J.P.R., Santos-Silva A. 2020. A new species of Neocompsa (Neoibidionini), and a new species and new combinations in Tillomorphini (Cerambycidae, Cerambycinae) // Zootaxa. Vol.4748. P.334-350.

Holzschuh C. 2009. Beschreibung von 59 neuen Bockkäfern und vier neuen Gattungen aus der orientalischen und palaearktischen Region, vorwiegend aus Laos, Borneo und China (Coleoptera, Cerambycidae) // Entomologica Basiliensia et Collectionis Frey. Bd.31. S.367-358.

Holzschuh C. 2019a. Zur Synonymie und neun neue Taxa von Bockkäfern aus Asien (Coleoptera, Cerambycidae) // Les Cahiers Magellanes (NS). Vol.32. P.58-73.

Holzschuh C. 2019b. Zur Synonymie und zehn neue Taxa von Bockkäfern aus Asien (Coleoptera, Cerambycidae) // Les Cahiers Magellanes (NS). Vol.33. P.86-103.

Hüdepohl K.-E. 1990. The longhorn beetles of the Philippines. Part II // Entomofauna. Zeitschrift fur Entomologie. Bd.11. Hf.3/1. S.45-102.

Knull J.N. 1946. The long-horned beetles of Ohio (Coleoptera, Cerambycidae) // Ohio Biological Survey, Bulletin. Vol.39. No.7. P.133-354

Lacordaire J.T. 1868. Histoire naturelle des insectes. Genera des Coleopteres, ou expose methodique et critique de tous les genres proposes jusqu'ici dans cet ordre d'insectes. T.8. 1869. Paris: Librairie encyclopedique de Roret. 552 pp. + pls 81-91.

Lacordaire J.T. 1869. Histoire naturelle des insectes. Genera des Coléoptères, ou exposé méthodique et critique de tous les genres proposés jusqu'ici dans cet ordre d'insectes. T.9. Pt.1. Paris: Librairie encyclopédique de Roret. 409 pp. + pls 92-100.

Lingafelter S.W. 2011. New myrmecomorphous longhorned beetles from Haiti and the Dominican Republic with a key to Anaglyptini and Tillomorphini of Hispaniola (Coleoptera, Cerambycidae, Cerambycinae) // ZooKeys. Vol.106. P.55-75. doi: 10.3897/zookeys.106.1470 
Lingafelter S.W., Nearns E.H. 2007. Five new species of longhorned beetles (Coleoptera: Cerambycidae) from the Dominican Republic in genera Ataxia Haldeman, Atimiola Bates, Drycothaea Thomson, Eburia Lepeletier \& Audinet-Serville, and Hormathus Gahan // The Coleopterists Bulletin. Vol.61. No.2. P.177-191.

Linsley E.G. 1935. Studies in the Longicornia of Mexico (Coleoptera: Cerambycidae) // Transactions of the American Entomological Society. Vol.61. P.67-102.

Linsley E.G. 1964. The Cerambycidae of North America. Part V. Taxonomy and classification of the subfam. Cerambycinae, tribes Callichromini through Ancylocerini. University of California Publications in Entomology. Vol.22. P.1-197.

Löbl I., Smetana A. (Eds). 2010. Catalogue of Palaearctic Coleoptera. Vol.6. Chrysomeloidea. Stenstrup: Apollo Books. 924 pp.

López-Pérez J.J. 2005. Encontrar rápidamente la clasificación de los Cerambycidae del mundo (Coleoptera: Chrysomeloidea) // Boletin de la Sociedad Entomológica Aragonesa. No.13. P.44-66.

MacRae T.C. 1994. Annotated checklist of the longhorned beetles (Coleoptera: Cerambycidae and Disteniidae) occurring in Missouri // Insecta Mundi. Vol.7. No.4. (1993). P.223-252.

MacRae T.C., Bezark L.G., Swift I. 2012. Notes on distribution and host plants of Cerambycidae (Coleoptera) from southern México // The Pan-Pacific Entomologist. Vol.88. No.2. P.173-187.

Makihara H. 1999. Atlas of longicorn beetles, in Bukit Soeharto Education Forest, Mulawarman University, East Kalimantan, Indonesia. Pusrehut special publication No.7. 140 pp.

Makihara H., Saito A., Chu Y.-I., Hayashi M., Nakamura S. 1989. A list of cerambycid-beetles from Taiwan (III). Subfamily Cerambycinae // Chinese Journal of Entomology. Vol.9. No.2. P.289300 .

Maquart P.-O., Van Noort S. 2017. Description of a new species of Capederces (Coleoptera: Cerambycidae: Cerambycinae) from South Africa // Zootaxa. Vol.4244. P.583-587.

Martínez C. 2000. Escarabajos longicornios (Coleoptera: Cerambycidae) de Colombia // Biota Colombiana. Vol.1. No.1. P.76105.

Martins U.R., Galileo M.H.M. 2005. Cerambycidae (Coleoptera) da Colômbia. VII. Novos táxons, novos registros, nova sinonímia nova combinação e novo nome // Revista Brasileira de Zoologia. Vol.22. No.1. P.5-18

Matsushita M. 1933. Beitrag zur Kenntnis der Cerambyciden des japanischen Reichs // Journal of the Faculty of Agriculture of the Hokkaido Imperial University. Vol. 34. Pt. 2. P. 157-445+ pls $1-5+\mathrm{i}-\mathrm{x}$.

McKeown K.C. 1947. Catalogue of the Cerambycidae (Coleoptera) of Australia // Australian Museum. Memoir 10. P.1-190.

Micheli J.A. 2010. Longicornios de Puerto Rico (Coleoptera: Cerambycidae). Pensoft Publishers. 298 pp.

Miroshnikov A.I. 2014. A review of the genus Clytellus Westwood, 1853 , with notes on its systematic position and descriptions of eleven new species (Coleoptera: Cerambycidae) // A.S. Konstantinov, S.A. Ślipiński, A.Yu. Solodovnikov (Eds). Advances in studies on Asian cerambycids (Coleoptera: Cerambycidae). Papers by Alexandr I. Miroshnikov, dedicated to the memory of Dr. Judson Linsley Gressitt. Krasnodar-Moscow: KMK Scientific Press Ltd. P.133-237.

Miroshnikov A.I. 2015. Additions to reviewing the genus Clytellus Westwood, 1853 (Coleoptera: Cerambycidae). 1 // Caucasian Entomological Bulletin. Vol.11. No.2. P.369-381, color pls5-8.

Miroshnikov A.I. 2020. Contribution to the knowledge of the genus Calliclytus Fisher, 1932 (Coleoptera: Cerambycidae: Cerambycinae: Tillomorphini), with a new synonymy and description of a new species from the Dominican Republic // Russian Entomological Journal. Vol.29. No.3. P.261-270. doi: 10.15298/ rusentj.29.3.04

Miroshnikov A.I., Tichý T. 2015. Additions to reviewing the genus Clytellus Westwood, 1853 (Coleoptera: Cerambycidae). 2 // Caucasian Entomological Bulletin. Vol.11. No.2. P.383-384, color pls $9-10$.

Miroshnikov A.I., Tichý T. 2018. A new genus and species of the longicorn beetle tribe Tillomorphini Lacordaire, 1868 (Coleoptera: Cerambycidae) from India // Russian Entomological Journal. Vol.27. No.2. P.153-155. doi: 10.15298/rusentj.27.2.05
Mitono T. 1940. 94. Cerambycidae // Catalogus Coleopterorum Japonicorum. Pars 8. Taihoku: Noda-Syobo. 283 pp.

Monné M.A. 1993. Catalogue of the Cerambycidae (Coleoptera) of the western hemisphere. Part IX. Subfamily Cerambycinae: Tribes Clytini, Anaglyptini, Tillomorphini and Cleomenini // Sociedade Brasileira de Entomologia. Vol.9. P.1-131.

Monné M.A. 2001. Catalogue of the Neotropical Cerambycidae (Coleoptera) with known host plant - Part II: Subfamily Cerambycinae, Tribes Graciliini to Trachyderini // Publicações Avulsas do Museu Nacional. Vol.90. P.1-119.

Monné M.A. 2005. Catalogue of the Cerambycidae (Coleoptera) of the Neotropical Region. Part I. Subfamily Cerambycinae // Zootaxa. Vol.946. P.1-765.

Monné M.A. 2012. Catalogue of the type-species of the genera of the Cerambycidae, Disteniidae, Oxypeltidae and Vesperidae (Coleoptera) of the Neotropical Region // Zootaxa. Vol.3213. P.1-183.

Monné M.A. 2020. Catalogue of the Cerambycidae (Coleoptera) of the Neotropical Region. Part I. Subfamily Cerambycinae. 1122 pp. Available from: https://cerambycids.com/catalog/

Monné M.A., Bezark L.G. 2011. Checklist of the Cerambycidae and related families (Coleoptera) of the Western Hemisphere 2011 Version. 469 pp. Available from: https://www.cerambycoidea.com/ papers.asp

Monné M.A., Bezark L.G., Hovore F.T. 2007. Checklist of the Cerambycidae, or longhorned beetles (Coleoptera) of the Western Hemisphere. 417 pp.

Monné M.A., Giesbert E.F. 1995. Checklist of the Cerambycidae and Disteniidae (Coleoptera) of the Western Hemisphere. Burbank: Wolfsgarden Books. i-xiv +419 pp.

Monné M.A., Hovore F.T. 2005. Electronic Checklist of the Cerambycidae of the Western Hemisphere. 393 pp.

Monné M.L., Monné M.A., Martins R.S., Simões M.V.P., Machado V.S. 2009a. Espécies de Cerambycidae (Insecta, Coleoptera) ocorrentes no Estado do Rio de Janeiro (Brasil) // Arquivos do Museu Nacional (Rio de Janeiro). Vol.67. Nos3-4. P.235-251.

Monné M.L., Monné M.A., Mermudes J.R.M. 2009b. Inventário das species de Cerambycinae (Insecta, Coleoptera, Cerambycidae) do Parque Nacional do Itatiaia, RJ, Brasil // Biota Neotropica. Vol.9. No.3. P.283-312.

Napp D.S. 1994. Phylogenetic relationships among the subfamilies of Cerambycidae (Coleoptera, Chrysomeloidea) // Revista Brasileira de Entomologia. Vol.28. No.2. P.265-419.

Niisato T. 2015. Discovery of the Genus Clytellus Westwood (Coleoptera, Cerambycidae) from Eastern Taiwan // Elytra. Tokyo. N.S. Vol.5. No.2. P.495-499.

Noguera F.A., Zaragoza-Caballero S., Rodríguez-Palafox A., González-Soriano E., Ramírez-García E., Ayala R., OrtegaHuerta M.A. 2012. Cerambícidos (Coleoptera: Cerambycidae) del bosque tropical caducifolio en Santiago Dominguillo, Oaxaca, México // Revista Mexicana de Biodiversidad. Vol.83. P.611-622.

Pascoe F.P. 1869 [1864-1869]. Longicornia Malayana; or, a descriptive Catalogue of the species of the three Longicorn Families Lamiidae, Cerambycidae and Prionidae, collected by Mr. A.R. Wallace in the Malay Archipelago // The Transactions of the Entomological Society of London. Vol.3. Ser.3. Pt.7. P.553$710+$ pls 21-24.

Pascoe F.P. 1871. Descriptions of new genera and species of longicorns, including three new subfamilies // The Annals and Magazine of Natural History. Vol.8. Ser.4. No.46. P.268-281 + pl. 13.

Peck S.B. 2005. A checklist of the beetles of Cuba with data on distributions and bionomics (Insecta: Coleoptera) // Arthropods of Florida and Neighboring Land Areas. Vol.18. P.1-241.

Peck S.B. 2011. The beetles of Martinique, Lesser Antilles (Insecta: Coleoptera); diversity and distributions // Insecta Mundi. No.0178. P.1-57.

Peck S.B., Perez-Gelabert D.E. 2012. A summary of the endemic beetle genera of the West Indies (Insecta: Coleoptera); bioindicators of the evolutionary richness of this Neotropical archipelago // Insecta Mundi. No.0212. P.1-29.

Peck S.B., Thomas M.C. 1998. A distributional checklist of the beetles (Coleoptera) of Florida // Arthropods of Florida and Neighboring Land Areas. Vol.16. P.1-180. 
Philippi F. 1887. Catálogo de los Coleópteros de Chile (Conclusión) // Anales de la Universidad de Chile. Vol.71. No.1. P.767-778.

Plavilstshikov N.N. 1931. Cerambycidae I. Teil. Cerambycinae: Disteniini, Cerambycini I (Protaxina, Spondylina, Asemina, Saphanina, Achrysolina, Oemina, Cerambycina) // Bestimmungs-Tabellen der europäischen Coleopteren. Hf.101. Troppau. 102 ss.

Plavilstshchikov N.N. 1940. Fauna SSSR. Nasekomye zhestkokrylye. T.22. Zhuki-drovoseki (Ch.2) [Fauna of the USSR. Insects, Coleoptera. Vol.22. Longhorn beetles (Pt.2)]. Moscow - Leningrad: Academy of Sciences of the USSR. 785 pp. [In Russian with an extensive summary in German]

Porter C.E. 1930. Nueva localidad de un cerambicido // Revista Chilena de Historia Natural. Vol.34. P.48.

Shelford R. 1902. Observations on some mimetic insects and spiders from Borneo and Singapore [With appendices containing descriptions of new species by R. Shelford, K. Jordan, C.G. Gahan, R.H.S. Gorham, A. Senna] // Proceedings of the general meetings for scientific business of the Zoological Society of London. Vol.2. No.4. P.230-284 + pls 19-23.

Ślipiński S.A., Escalona H.E. 2016. Australian Longhorn Beetles (Coleoptera: Cerambycidae). Vol.2. Subfamily Cerambycinae. Csiro publishing. P.iii-Xvi + 1-613.

Solervicens J., Elgueta M. 1989. Entomofauna asociada al matorral costero del norte Chico // Acta Entomologica Chilena. Vol.15. P.91-122.

Strauch A. 1861. Catalogue Systématique de tous les Coléoptères décrits dans les Annales de la Société Entomologique de France depuis 1832 jusqu'à 1859. Halle: H.W. Schmidt. i-iv $+159+[1]$ pp.

Swift I.P., Bezark L.G., Nearns E.H., Solís Á., Hovore F.T. 2010. Checklist of the Cerambycidae (Coleoptera) of Costa Rica. // Insecta Mundi. Vol.0131. P.1-68.

Tavakilian G.L., Chevillotte H. 2020. Titan: base de données Titan sur les Cerambycidés ou Longicornes. Available at: http:// titan.gbif.fr/ (accessed 17 October 2020).

Thomson J. 1861. Essai d'une classification de la famille des Cérambycides et matériaux pour servir à une monographie de cette famille. Paris: chez l'auteur [James Thomson]. P.129-396 + 3 pls.

Thomson J. 1864. Systema Cerambycidarum ou exposé de tous les genres compris dans la famille des Cérambycides et familles limitrophes. Liège: H. Dessain. P.1-352.

Touroult J. 2014. Nouveautés taxonomiques et faunistiques concernant les longicornes des Petites Antilles (Coleoptera, Cerambycidae) // ACOREP-France: Coléoptères des Petites Antilles. T.2. P.82-89.

Turnbow R.H., Cave R.D., Thomas M.C. 2003. A list of the Cerambycidae of Honduras, with additions of previously unrecorded species // Ceiba. Vol.44. No.1. P.1-43.

Villiers A. 1980. Coléoptères Cerambycidae des Antilles françaises. II. Cerambycinae // Annales de la Société Entomologique de
France (n.s.). T.16. No.2. P.265-306

Vitali F. 2010. Catalogue of the types of the Cerambycoidea of the National Museum of Natural History of Luxembourg // Bulletin de 1'Institut Royal des Sciences Naturelles Belgique (Entomologie). Vol.80. P.109-126.

Vitali F. 2017. Two new fossil species of Tillomorphites Vitali (Coleoptera: Cerambycidae) and remarks on the morphological evolution, mimicry, biogeography and phylogeny of the tribe Tillomorphini // Baltic Journal of Coleopterology. Vol.17. No.2. P.147-160.

Vives E. 2015. New or interesting Cerambycidae from the Philippines (Part X) (Coleoptera, Cerambycidae, Cerambycinae) // Les Cahiers Magellanes (NS). Vol.18. P.1-18.

Vlasák J., Santos-Silva A. 2020. New species of Cerambycinae and Lamiinae from Ecuador and Honduras, with transference of a species of Rhinotragini (Coleoptera, Cerambycidae) // Zootaxa. Vol.4748. P.455-470.

Wappes J.E., Morris II R.F., Nearns E.H., Thomas M.C. 2006. Preliminary checklist of Bolivian Cerambycidae (Coleoptera) // Insecta Mundi. Vol.20. Nos1-2. P.1-45.

Weigel A. 2006. Checklist and bibliography of longhorn beetles from Nepal (Insecta: Coleoptera: Cerambycidae) // M. Hartmann, J. Weipert (Eds). Biodiversität \& Naturausstatung im Himalaya. Bd.2. Erfurt: Verein der Freunde und Förderer des Naturkundemuseums Erfurt e.V. S.495-510.

Weigel A., Meng L.-Z., Lin M.-Y. 2013. Contribution to the fauna of longhorn beetles in the Naban River Watershed National Nature Reserve. Formosa Ecological Company. 219 pp.

Westwood J.O. 1853 [On some new Coleoptera from China and Ceylon, with a notice of the habits of the Coleoptera of Hong Kong] // The Annals and Magazine of Natural History. Vol.11. Ser.2. No.66. P.480-481.

Westwood J.O. 1854 [1852-1853]. Descriptions of some new species of Coleoptera from China and Ceylon // The Transactions of the Entomological Society of London. Vol.2. N.S. Pt.7. P.232$241+$ pl. 12 .

White A. 1855. Catalogue of the Coleopterous Insects in the Collection of the British Museum. Pt. 8. Longicornia 2. London: Taylor and Francis. P.175-412 + pls 5-10.

Winkler A. 1929. Phytophaga. Cerambycidae // Catalogus Coleopterorum regionis palaearcticae. Pars 9-10. Wien: Albert Winkler. P.1135-1226.

Wu C.F. 1937. Catalogus insectorum sinensium (Catalogue of Chinese insects). Vol.3. Peiping: The Fan Memorial Institute of Biology. 1312 pp. (Cerambycidae: p.665-775).

Zayas F. 1975. Revision de la familia Cerambycidae (Coleoptera, Phytophagoidea). Havana: Academia de Ciencias de Cuba, Instituto de Zoologia. $443 \mathrm{pp}$. 